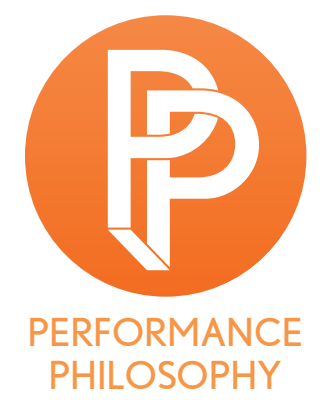

\title{
ASH STORIES: A SPELL AGAINST FORGETTING
}

\section{MADELEINE COLLIE MONASH UNIVERSITY}

One evening I was driving home through a mist shrouded wood when I noticed a large stand of trees that had recently been felled. Only a few months earlier, in late summer of 2019, I had walked through this wood with a group of people on the way to see the public art sculpture Ash to Ash by Ackroyd \& Harvey that I had helped to bring into existence. The memorial now stands on the crest of the chalky ridge that formed the Kent downs millennia ago. The path we walked traces this elevation and is known as the Pilgrim's Way, an ancient route that connects the outskirts of London to Rome. The woodland along the downs in this spot is a patchy mixed ash and broadleaf woodland. It is, as most woods in southern England are, crossed with walking paths. The night was settling, a soft rain was falling. I stopped my car in the middle of the lane, walked through muddy debris and touched one of the ash tree stumps. In the strange dusky light produced by my headlights, I said goodbye to the trees.

In this paper I discuss The Ash Project: a curatorial strategy and a memorial process that told the fragmented story of a changing treescape across the Kent Downs. For three years, 2016-2019, I worked across this landscape with The Ash Project to trace the decline of native European ash trees (Fraxinus excelsior or common ash) caused by a fungal pathogen that induces ash dieback. I worked as the curator on this project, then in early 2020 I returned to Australia. In this essay I explore the science of the disease, the stories that are told about ash through Europe, travelling from the birth of language to the present plant industrial complex, speculating on the capitalist entanglements in some of the proposed strategies of population recovery. What I hope to highlight in this section is that the complexity of the management approaches being proposed to recover ash species, much like the management of the human pandemic of Covid-19, cover a range of opinion and those that manage ash woodlands and sites vary widely in their views. Given that much of the ash landscape 
is managed by different agencies, landowners and scientific bodies, consulting with these groups revealed the complexities of navigating approaches to plant pandemics in the future. Because of a dramatic shift in place that I performed from the time of this essay being proposed to the time of writing, taking up a new place in the world brought new light, for me, to the story of ash tree. In the next section of the essay, I explore ash tree migration to Australia to reflect on the way in which our view of ecologies both in Australia and in the UK are shaped by colonial histories.

Finally, I return to The Ash Project to ask whether the active process of building a community for a public memorial, such as the one performed by The Ash Project, could be seen as a strategy for embracing 'ethical relationality' and perhaps even kinship with plants. I ask whether such memorials can acknowledge the complex relationship between plants, colonisation, people and place, while considering whether it is possible to form kin relations with plants in ways that are removed from the capitalist entanglements of their management, planting, growing? Are creative or curatorial practices one way of carving out a place for experiments with other kinds of relationships with plants? In this tangled mess of living and dying, what kinds of collective acknowledgement of such disruption can we imagine? The memorial, both as a site and as a process, advocates a deep attention to trees and their suffering, which might also encourage us to act differently.

This essay draws insights from science, humanities, genetics, economics, botanical histories, mythologies and indigenous relationality. I attempt to elaborate a complex picture of human relations with and to the ash tree. Anna Lowenhaupt Tsing makes the argument that science is a translation machine. It is machinic, she says, because "teachers, reviewers, and peer reviewers stand ready to chop off excess parts" and it is translational because "its insights are drawn from diverse ways of life" (Tsing 2015, 217). Through The Ash Project I walked with scientists, artists, poets, wood workers, economists, rangers, foresters, ecologists. Over time, through walking I developed an affective and storied understanding of ash trees. Walking is a curatorial strategy that became a way of assembling a complex understanding of the ecological issues at stake in the loss of the ash. The Ash Project was a process of translating diverse insights to a wider public through walking, listening to trees, sharing knowledge. At the same time, it became a process of unlearning, as I began to turn towards ash trees with different senses. In this essay I hope to share this storying with the reader. I don't believe there is a right way to shape plant knowledge, and as Tsing says "landscapes and landscape knowledge develop in patches" (227). I hope you will read this as a patchy translation of some of the things that stayed with me along the way.

Telling ash stories, repeating them, sharing them, shaping them, is an act of love, an act of remembering. In telling the stories that shape this essay and even repeating them as we did throughout The Ash Project might be a way of casting a spell to resist the forgetting of our own implicated and embodied relations, which might be one of the many tricks that modernity plays on us. To recall that ash were once our ancestors and healers, that each species under threat of extinction has been with us on this earth for many thousands of years and as such shares our history. Human history is not only human. This essay conjures ash stories, with the hope that such a spell against forgetting might be a way to call new futures into existence. 
The Ash Project was conceived by the team at the Kent Downs Area of Outstanding Natural Beauty (AONB). The director, who cares deeply about ash trees dying across Europe, wanted to create a memorial process that would tell the story of their changing landscapes. As well as the memorial sculpture by artist and activists Ackroyd \& Harvey, I worked with partner organisations to commission walks, talks, workshops, new writing, tree planting and identification, film screenings and exhibitions to create a patchwork of relationships between ash trees and local publics in Kent. We programmed over sixty walks, including a series of walks with artists and collectives; Adam Chodzko, Hannah Lees, The Walking Reading Group, and Feral Practice: Fiona Macdonald and Marcus Coates. We held a series of exhibitions called The Ash Archive which ran across five locations in Kent over three months. Alongside significant ash artworks, members of the public could bring in objects, stories, poems, artworks and photographs of ash and have them catalogued. We traced a history of ash works of art in the UK from John Constable (Stafford 2016) and Henry Moore to the planting of David Nash's Ash Dome in 1976 and many artists beyond. We worked with schools across the county, and ran workshops in craft, chair making and carving. We worked with the Woodland Trust to produce localised surveys of the loss that would be caused by ash dieback and built a landscape wide recovery programme (which is still running) to encourage landowners to put in replacement species that might support the communities of life that would be impacted by the loss of ash. We planted over 1000 trees; including new forest connectivity areas and the next generation of other species to replace ash in ash dominated landscapes. The programme centred on the launch of a memorial sculpture by Ackroyd and Harvey. A pair of monolithic deceased ash trees, standing ten meters tall. One charred and blackened, the other stripped and bleached pale. Each speared with over 10,000 ash arrow staves hand carved by Essex wood turners Tom Mareschall and Adam Jenkins. The sculpture now sits on a scarp overlooking the Weald of Kent on the edge of an ash woodland planted at the turn of the millennium which is now ravaged by the disease. At a launch of the sculpture with over a hundred and fifty people in attendance singers chanted fragments from a text by Hildegard von Bingen as part of 'Viritidas,' a choral composition and enchantment for the protection of green places by artist musician Anil Sebastian. Together we told the story again and again, as though casting a spell against forgetting the ash. 


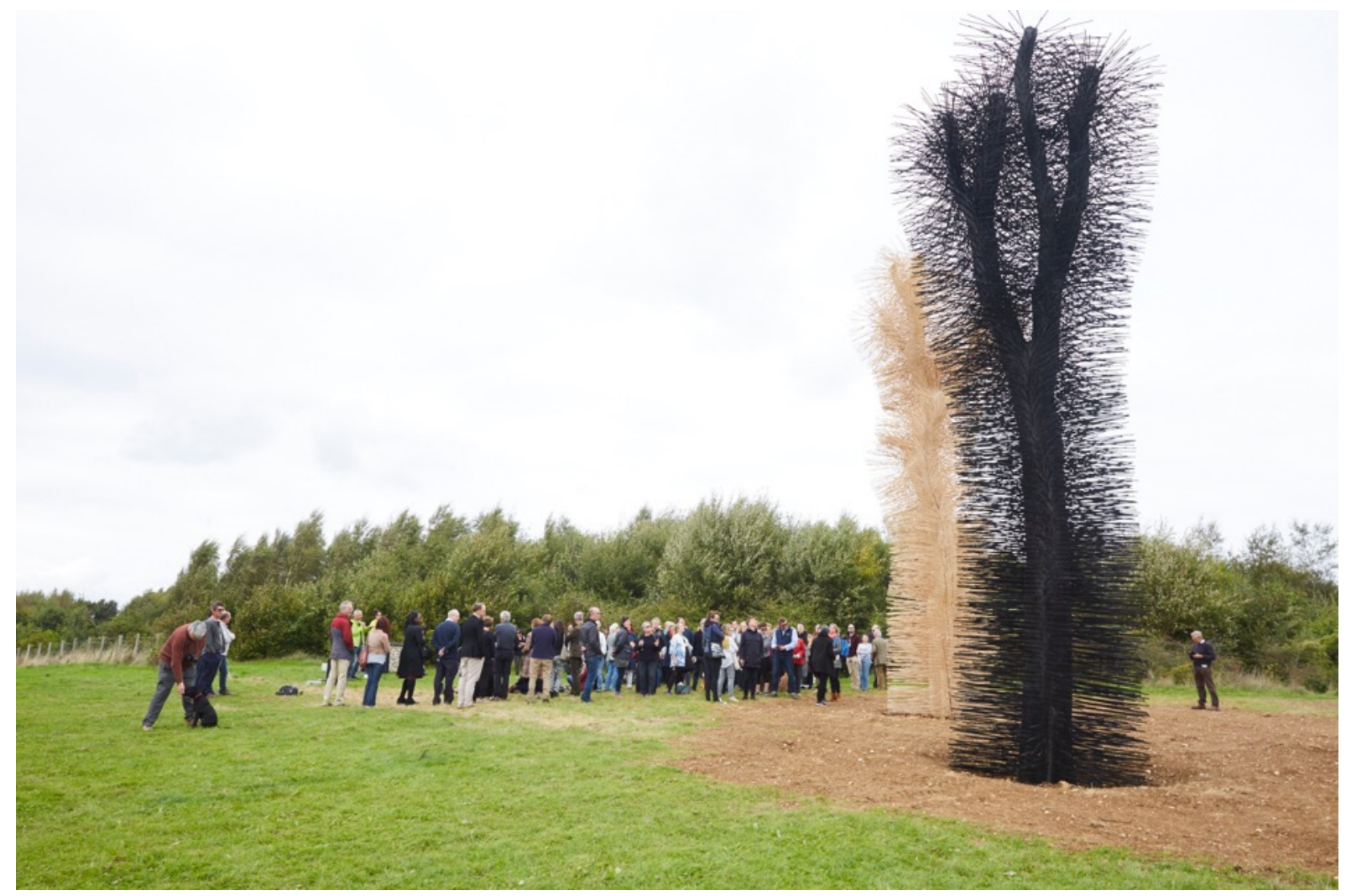

Figure 1: Ackroyd \& Harvey, Ash to Ash, White Horse Wood, Kent Downs, 2018. Photo: Manuel Vason

\section{Ash Dieback}

In Europe and in the US, many varieties of ash trees are dying. Different threats to their health, including Emerald Ash Borer and Hymenoscyphus fraxineus (the fungal pathogen that causes ash dieback), have the trees in a pincer grip. A slow death contributing to an extreme decline in ash populations across the northern hemisphere. A quick look through the International Union for Conservation of Nature (IUCN) red list database of threatened species reveals that, of the major varieties of Fraxinus (ash) across the world, fourteen key species are threatened, vulnerable or critically endangered (Khela and Oldfield 2018). The Kent coast, where The Ash Project started, forms a border between Britain and mainland Europe. It is part of the colonial story of the displacement of plants across trading regions. The wind-borne pathogen travels across landscapes, infecting ash trees as it goes. The tiny innocent spores of the fungus enter the tree via the rachis, the long thin stem of their leaves. It spreads into the branches and then the trunk (Forest Research 2021). The pathogen produces a chemical called viridiol which causes necrosis in the sapwood and cuts off supply of nutrients and waters from the roots (Andersson et al. 2009). Necrosis makes the leaves to turn black and fall off the tree. The fungus sojourns in the infected leaf litter at the base of the tree, hibernating overwinter. It spores again in spring when it reinfects the ash, trapping the tree in a cycle of decline. Its vascular system weakens which in turn exposes the trees to other diseases which will eventually kill them (Forest Research 2021). The pathogen that causes ash dieback (or Chalara dieback of ash) is known to have originated in an Asian ash 
species called Fraxinus Manchuria. In this ash species the fungus coevolved alongside the tree and so the trees' immune systems adapted with the fungus and enabled it to live in harmony with its host (ibid.).

The UN's Food and Agriculture Organisation named 2020 the Year of Plant Health because of the increasing risks from introduced pests through trade, travel and changing climates. The website indicates that plant health pandemics have the potential to impact the way we grow food, rebuild forests and care for soils and ecosystems. Many experts credit the accelerations of global trade in the 1970s as marking a key moment in the ways in which diseases migrated with 'plant stocks' across borders. Plant trade and the capitalist desire for more and more 'cheap nature' led to the introduction of pests to new environments, inadvertently killing off millions of trees in the process. Clive Potter and Julie Urquhart, two researchers who were engaged early on with The Ash Project, write "tree disease outbreaks and pest invasions are likely to become permanent features of the Anthropocene forest landscape-and many of them are traceable, with varying degrees of directness, to commercial interests and human behaviour" (Potter and Urquhart 2017, 63).

Ash dieback disease was 'discovered' first in a plant nursery in the UK in Buckinghamshire in 2012 (65), but theories abound about its actual arrival. Some believe that it could have been introduced via the mass planting of ash that took place after the development of the Eurotunnel as early as the mid 1990s. The presence of ash dieback was known in European forests at this time and a failure to stop these imports has been seen by some as a mistake. Though as Potter and Urquhart note, "confusion surrounding the taxonomic classification of the disease being observed on the continent and the extent of its pathogenicity did not help matters" (65). Following the destruction caused to local ecosystems by the development of the tunnel, imported ash saplings-which at that time were grown much cheaper on the continent-are thought to have been brought in to replace trees along either side of the new infrastructure. Many people I met while working on The Ash Project quietly speculated to me that in the process of planting these saplings ash dieback was introduced to Kent. Jason W. Moore, author of Capitalism in the Web of Life, cites feedback loops such as this as evidence that we need to see capitalism as a world ecological process: capitalism exists in nature and nature is produced by capitalism (Moore 2015, 33). Moore develops the concept of the oikeos as a way of asking us to think of capitalism as a world ecological event. He writes, "Yes diseases make history, but only as epidemiological vectors bound to commerce and empire" (37). To him, these loops are nature's way of saying that it's not going to work for free anymore.

\section{Ash Stories}

Ash trees have had an important place in European myth and economies. And the trees swirl with stories of making and unmaking. In parts of northern Europe, including across Scandinavia ash trees are planted on the edge of farms to mark the boundary and they act as a form of protection for the land. Because of its long straight grain, ash wood has been the material of choice for making tool handles, spears, arrows and domestic furniture. It was used to make war planes in the two world wars-namely, the Sopwith Camel and the Mosquito (Stafford 2016). Across Europe, ash 
trees are deeply entwined with the mythopoetic shape of many landscapes. In Norse mythology, an ash is the world tree, Yggdrasill, the tree of insight, the tree that connects the nine realms (Abram 2019). It is one of the twenty trees that make up the Celtic alphabet. Within the Ogham-one of the earliest written languages-ash is nion (n), the fifth letter (MacKillop 2004). Fiona Stafford writes in her book The Long, Long Life of Trees that "bunches of ash keys were boiled to create an aphrodisiac." (Stafford 2016, 117). Ash trees are associated with love, with healing the loneliness of the human spirit, ancient magic, and the divine feminine; as such, they are often called the 'Venus of the woods' (ibid, 117). The poet Hesiod, from whom we inherit cosmogony and early accounts of Gaia, wrote that the Melian (ash tree) Nymphs were the mothers of the Bronze race, the first recognisable human beings in the Greek mythic order: "father Zeus made a third race of mortal men, of bronze, not at all like the Silver Race, begotten by the ash-tree nymphs, fearsome and powerful. They were concerned only with the groans and violence of Ares" (Hesiod 2017, 115). According to Hesiod, ash trees are our European ancestors; if these stories tell us anything, it is that we once revered trees without separation, learnt to think through language alongside them, and perhaps in a distant ancestral memory; felt their flesh as our flesh.

Hymenoscyphus fraxineus has already decimated ash populations across many European countries. In the UK, forest scientists believe that in the next twenty years or so, the disease will result in an up to 95 per cent loss of over 180 million ash trees across the four countries or 2.2 billion if you are to include saplings (Forest Research 2021). Ash is one of a handful of trees that are native to northern Europe, which is important from a conservation perspective in that these trees are able to provide support to a wider network. Ash hosts communities of almost 1,000 other-than-human creatures and species. Under all management scenarios predicted for the outbreak, all of the more-than-human companions that are obligate to ash are predicted to decline or face extinction within 50-100 years (Broome and Mitchell 2017). Reports of a sharp increase in the loss of biodiversity in Europe track alongside these alarming stories of tree populations in decline. While researching for The Ash Project, I met some scientists who were cavalier about this loss; they would say that the ash populations are likely to recover in around 500-1,000 years. Still others preferred the language of politicians, using figures and calculations to sound a warning about threats to the 'eco-system services' that ash trees provide for market and non-market values-from flood mitigation, clean air and soil health to biofuels and furniture. These stories are also part of the making and unmaking of the ash tree. They raise alarms about the relationship between science and politics and demonstrate how far we have come from revering ash as our kin.

Many forests in Europe are already filled with dead trees. They linger like ghosts in the landscape. The loss of ash will be vast. In sites where ash is dominant, new species will take their place, changing the light in the forests, which in turn will change the plant life around the trees, including moss and lichen. This impacts birds, butterflies, moths and insect populations that all rely on ash in one way or another. Loss always occurs as a chain of events. As Helen Macdonald writes, it's hard to trace back to what we once had: "But perhaps when all the ash trees are gone and the landscape has become flatter and simpler and smaller, someone not yet born will tap on a screen, call up images and wonder at the lost glory of these exquisite, feathered trees" (Macdonald 2015, par. 10). 
One particular wood that I visited, over and over, during the course of the three years was Asholt or Ashley wood. Named for its abundance of ash trees it is considered one of best examples of a coppiced ash woodland in the county of Kent. It is a protected wood, listed as a Site of Special Scientific Interest (Natural England 2021), a tiny fragment of a once thriving way of life. It contains 'indicator' species that signal to observers that it is an ancient and ecologically significant site. The designation document reports that "It has an outstanding lichen flora and a diverse breeding bird community. The site also supports an outstanding assemblage of insects including many local and rare species" (ibid.). The wood is accessed via a small car park that runs behind the road that leads to the Channel Tunnel that connects Folkestone, UK to Calais in France.

Following an old railway track you eventually come to the gate, and over the stile you see a mostly dead ash wood before you. The tops of the ash trees are defoliated, with extra growth closer to the centre of each tree, and too much epicormic growth along the branches. Ash have a pale grey bark that in certain conditions make them appear almost white. Below these ghost trees are a thick wood of shorter species: hazel, field maple. Lower again, dogwood and spindle which flourish in the changing light that the newly dying trees creates. As you walk along the path at the top of the bank of grassland to the edge of the wood, the undergrowth appears dense and grown wild. Entering the wood over a small clay stream the trees above are thin and wispy. This tiny fragment of woodland has been neglected for many years. It was once a place that was managed for wood; ash, hazel and hornbeam coppiced tree stumps are a record of that time. Now, as these local industries fade into memory, the lands are leased by the Ministry of Defence for army training drills. I walked through this wood with many different experts, foresters, land managers and government officials. On one day with a group interested in how we might better care for ancient forests, we searched the woodland for ground flora; herb paris, stinking iris and enchanter's nightshade, indicators of biodiversity that has shrunk across the county. On another walk with forestry experts, we talked about the risk to walkers from falling dead trees. By this point the military were no longer using the wood because of the threat of deadly branches. There were rumours that arborists had died in Wales from trying to remove some trees affected by dieback. The wood becomes dry as the tree dies, and it becomes more dangerous to fell. So, some foresters wanted to bring in giant mechanical harvesters to take all the dead trees away. Others involved in conservation and protection of biodiversity felt strongly that the Kent Downs AONB should work with partners to close the wood off to the public. Leave the dead wood to fall where it lay and to allow the patch of forest to take a new shape without human interference. All the people who joined us in the woods were responsible for managing large tracts of land (National Trust, Woodland Trust, Country Landowners Authority and many others) that will be impacted by ash dieback and we felt certain that among them there was no clear consensus about what a human response might be to the loss of ash. 


\section{Ash Genes}

Of the loss mitigation solutions that exist the one that seems to raise the most excitement is the genome sequencing of the tree which has successfully mapped ash genes for susceptibility to dieback and uncovered the genetics behind resistance. Trials have included growing trees directly from genetic materials, and also growing genetically selected seedlings, grafted onto root stock (Forest Research 2021). The selected seedlings are then exposed to the disease and the researchers wait a few years to see which trees survive. These test sites are a cruel installation. One trial plot that I visited many times is part of a Woodland Trust estate in Hucking, Kent. It is a gated field to quarantine the trees and prevent the spread of the deadly disease on walkers' muddy boots. Among over a hundred small, dying saplings only one or two are struggling to survive. If you have any feeling for plants, it's hard to watch. It's an infirmary of small trees all afflicted with disease.

Several woodlands across the UK are now being populated with trees grown from the survivors of genetically selected ash trees. These projects are popular in part because they reassure a public grown weary from stories of species loss and extinction that recovery in some form or other will be possible. Yet the strangeness of that future also needs to be felt, as we imagine not only survivors, but test tube trees grown from a narrowing clonal gene pool. Genetically selected trees are inherently weaker because they are not mixing traits with neighbouring trees which means they become even more susceptible to future threats (such as Emerald Ash Borer). In the case of the ash tree, genetic science merges uncomfortably with a nationalist English belief in the morality and purity of native plants in a 'green and pleasant' land. Ash is the most common tree in iconic English hedgerows. It is the second most common tree in woods and the third most common tree across all of the country (Department for Environment, Food \& Rural Affairs 2019). Genetics when it is wielded in this way might be a site for invasive bio-political governance, as Margarida Mendes writes in her essay 'Molecular Colonialism': "Our belief in genetic computability and its absolute control leads us to intervene in ecosystems in a manner that has led us to a regime of conflicted biopolitical sovereignty" (Mendes 2017, 135). If forest science and research programmes are in charge of what gets saved and on whose terms, that will eventually mean that some forms of life will be privileged over others. Is this already happening?

\section{Ash Economics}

Loss of ash in the UK is often reported in the media in economic terms and it is estimated to cost over 15 billion dollars (Woodland Trust 2021). It is reported in this way to shake us into action. But this is not a way of producing good relations, it's a way of producing debt. For me the question, in an era of escalating loss, of escalating debt, might be: on what basis are we to make such decisions about what to protect? Which species will draw the most attention and research? Which species will be saved? This conflict might lead us to ask what role does genetic late capitalist governance play in a future in which restoring degraded landscapes is going to be key? Could the design of such forests be left to a science that is often in service to the economic value systems that are in 
play at the time? Will this mean that some researchers will control patents of ecologically viable seedstocks? Are we to imagine whole forests hand planted by scientists?

In a 2016 report exploring climate change's impacts on ash, the authors end with a call not to abandon ash too soon; however, the language is striking: "While foresters are (currently) unwilling to invest in common ash planting, our results show that it is too early to abandon its exploitation" (Goberville et al. 2016, 7. Emphasis added). Genetic modification is an ancient human practice, and not all genetic engineering is to be distrusted. The point here is about who wields power over life on the planet and to what end? Bio governance at the scale that is being imagined attempts to atone for the risks to life presented by late-stage capitalism with the same logics that produced these risks in the first place. And it provides us with a convenient cover for, and distraction from, the ongoing implication of capitalist extraction on the ability of other forms of life to flourish. Does each resilient tree drive a deeper wedge into the split between nature and humans? Or does it accelerate unexamined notions of human centred wood-based capitalisms? With threats to plant health seen as one of the biggest risks to human life on the planet (Potter and Urqhart 2017, 65), these future landscapes seem unstoppable. In a hundred and twenty years from now we may well have a genetically selected landscape of ash trees (and other species) across the UK and Europe and perhaps no one will be able to tell the difference.

Bio algorithmic logics and modelling are presented as being able to calculate answers to the planetary crisis we face. Super computers crunch data about climate change. Satellites circle the earth recording the movements of the weather, inscribing land use patterns and ocean temperatures into the massive data systems held by NASA (NASA 2021). Climate change is known both to create increased risks to plant health and also to be one of the many overlooked metrics that could be plugged into the data system in order to more accurately predict where we are going. I've often wondered-without much success in securing an answer-whether there have been any inputs into climate change models of the impacts of tree disease across the planet. If we lose over two billion trees in the UK alone, this means, as Ariane Shahvisi writes, "three billion kilos of carbon dioxide a year won't be captured, equivalent to the annual emissions of 650,000 cars" (Shahvisi 2020).

According to the authors of 'Climate change and the ash dieback crisis,' research and modelling show that Hymenoscyphus fraxineus (the pathogen that causes ash dieback) might actually come into a sort of balance with the host species (ash) if temperatures in the northern regions of Europe warm with changing climates. The pathogen, which favours colder climates, will be pushed northward (Goberville et al. 2016). Here another strange feedback loop could be created; the loss of ash might increase the risk of climate change and the warming climate might reduce the risk of ash dieback. In some way, reading between the lines of this report, like some sort of sick joke, the key to a future for ash might actually be its own demise. Science reports on these strange loops all the time, mostly without irony and often without feeling. Planetary algorithms are not only a strange logic in which to put our faith; they also highlight the impossibility of modelling the current and coming loss. Every model that I have encountered makes vast assumptions about human behaviours, economic systems, legal structures. Imagining a future in which human relationships 
to nature remain exploitative and based on growth. Not only that, but authors also go to great lengths to remind us of the limitations of their fields of study. For instance, the authors of this report make this proviso among others, to remind readers of the limitations of their modelling: 'our model does not consider either additional projected infestations (e.g. the Emerald Ash Borer) or the effect of extreme climatic events that may affect existing populations strongly' (Goberville et al. 2016, 6). Similar papers define a limited field like this one to predict the future, while simultaneously keeping up the ruse that everything is computable. The authors of this paper are hopeful that their modelling will influence the governance of forest management. In the end perhaps such results can only be a form of speculative fiction. Margarida Mendes writes, "In the process what is rejected is the fact that life is itself an open system, non-linear, and exponentially chaotic" (Mendes 2017, 134).

\section{Ash Migration to Australia}

Ash trees of the Fraxinus varieties form part of the tree scape in Melbourne where I now live. They line suburban parks, roads in country towns, and city streets. While records of particular ash migrations are difficult to trace, the age of some street trees and Botanic Gardens records tell us that these plant movements occurred throughout the mid-late 1800s and mirrored colonial migration. Seeds were likely to have been brought to Australia in the pockets of botanists and introduced through acclimatisation societies. These societies, established in the 1850s and 60sfirst in Sydney 1852 and then in Melbourne 1861-were aimed explicitly at the 'improvement' of landscape. Vast experiments in transforming nature within society, to grow food, shape environments, and to make economies (Lever 2011). The website of Museums Victoria in Melbourne cites its founder Edward Wilson, a private collector, as having the motto "if it lives, we want it" (Tout-Smith 2003). Society members were 'men of science' who brought plants and animals from Europe and undertook experiments to introduce them to the new territory, thus leading a systematic programme of terraforming the country. The Botanic Gardens in Sydney and Melbourne were part of these experiments. Ferdinand von Mueller, director of the Royal Botanic Gardens in Melbourne from 1857 to 1873, is credited with introducing many 'exotic' plants to Victoria. In a lecture titled 'Application of Phytology in Relation to Industrial Pursuits: A Popular Discourse,' he lists an alarming number of trees from all over the world with which he planned to 'reforest' Victoria. At the end of the long list is ash: "[W]e want the various elastic Ash trees, which are so easily raised; we want indeed no end of other trees because the greater part of Victoria is illwooded, because our climate is hot and dry" (Von Mueller 1876, 93).

Tree diseases might be an unmappable planetary algorithm that starts here in the plant-based capitalist experiments of acclimatisation. A lecture given in 1862 by $\mathrm{Dr}$ George Bennett to the acclimatisation society in Sydney points to the destruction of European forests by moth larvae as one of the reasons for importing certain species of birds to Australia to combat such pests: "Man is unable to cope with the destroyers of the produce of his labour. His eye is too dull to perceive and his hand to slow to catch them" (Bennett 1862, 24). Nested within these speculative practices of terraforming land is the idea that capitalism, enlightenment values, Western imperialism, and 
industrial processes would fix nature, and thus transform the earth for market-is this where the current plant health crisis begins? Tracing this arc can provide a glimpse into the origins of a contemporary problem in the imperialist environment-making processes of colonial modernity. Histories of plant migration reveal that trade across vast distances increased risks to plant health and created latent threats that are only now being recognised. If research is needed into the causes of climate change and declining plant health, then perhaps we could start by reckoning with this colonial impulse to change, interfere, transform landscapes for profit. In the process severing living relations.

\section{Ash and the Anthropocene}

In Elwood, Melbourne, where I am currently based, on the lands of the Yalukut Weelam clan of the Boon Wurrung language group, only two percent of the precolonial vegetation survives (according to signage in a local park). Introducing plants and destroying native food and ceremonial plants was part of the colonial process, changing the vegetal imaginaries of urban spaces and terraforming the country that I now live on. In their article 'On the Importance of a Date or Decolonizing the Anthropocene,' Métis scholar Zoe Todd and Canadian settler writer Heather Davis cite this kind of mass migration of biological material —of which ash is just a small part-as marking the beginning of the so-called 'Anthropocene,' and they write "we argue that placing the golden spike at 1610, or from the beginning of the colonial period, names the problem of colonialism as responsible for contemporary environmental crisis" (Davis and Todd 2017, 763). The Anthropocene is a much-debated neologism that is used to describe anthropogenic changes to the planet that can be read in the geological layers. It is proposed as the name for the epoch to follow the Holocene (Zalasiewicz et al. 2020). Other scholars prefer Capitalocene (Moore 2015), Necrocene (John P. Clark, 2019) or Chthulucene (Haraway 2016) or, most appropriately for the ash, Plantationocene (Haraway and Tsing 2019). In their co-written article, Todd and Davis state: "These processes of environmental transformation and forced displacement can be understood as climate change, or more broadly, a preview of what it is like to live under the conditions of the Anthropocene" (Davis and Todd 2017, 771). They call this transformation 'terraforming' which means 'Earth shaping,' and for them it describes the massive changes to landscapes and country that were part of colonisation. The word is also now used widely in hypothetical discussions about creating the conditions for Earth-like life on other planets. Ash trees are part of our colonial feeling for spaces; while this migration is not the trees' fault, we can recognise, as feminist scholar Donna Haraway reminds us, that it matters "what thoughts think thoughts" and that we need to attend to the situated knowledges of plants here in Australia. This raises questions about what belongs where and what thoughts and histories are thinking with these trees. In Melbourne, street trees perform an archival map of the colonial terraforming imposed across the newly emerging colony. What is here is not what is meant to be here, or at least not what was here before we (settler colonial invaders) arrived. As Davis and Todd remind us, settler colonialism is always a process of a severing of relations "between humans and the soil, between plants and animals, between minerals and our bones" $(2017,771)$. 
On returning to Australia after living in England for almost a decade, I was surprised (naively, perhaps) to find ash trees on many urban streets and planted on the edge of farms to mark boundaries. As a child it was easy to accept these landscapes as part of a 'natural' ecosystem but after three years working in landscapes across the UK I can see now what an impact colonial plant migrations have had on a local view of what might be considered 'nature.' This means that in 'reading nature' we need to acknowledge the congress of multiplicities and layers of history, ancient and toxic that such readings imply. Raymond Williams writes that nature is the most complex word in English because it has a range of uses and, like culture, is a word that evolved from describing a 'process' to being a noun. In the case of nature 'out there,' or the way in which we use it to describe the material world, many readings coalesce. As he writes, "The real complexity of natural processes has been rendered by a complexity within the singular term" (Williams 1983). Robin Wall Kimmerer reminds us that the language of science too alienates us from the world. In her native tongue of Potawatomi, each living being is referred to through what she calls the "Grammar of Animacy" (Kimmerer 2013, chapter 4). Trees are each a someone and not something. She says language is "a mirror for seeing the animacy of the world, the life that pulses through all things, through pines and nuthatches and mushrooms. This is the language I hear in the woods; this is the language that lets us speak of what wells up all around us" (ibid).

\section{Ash Neighbours}

The practice of planting ash on the edge of a farm in the UK is a story that connects the past to the present-but in Melbourne this practice is a marker of colonisation imposed to designate possession of stolen lands. In some parts of Australia, some varieties of desert ash (Fraxinus angustifolia or Fraxinus oxycarpa) are now considered weeds by local councils. Plants are considered invasive when they are able to "invade relatively intact ecosystems" (State of Victoria 2020). In Australia it is widely recognised that one of the greatest threats to biological diversity is invasive species. Since colonisation, "some 26,000 plant species have been introduced to Australia by humans, significantly more than the 20,000 or so (recorded) extant species of native flowering plants" (Randall 2007). Even in their own habitats, ash trees are colonisers. Their propellor shaped seeds spread far on the wind, and they grow long tap roots that make them hard to dislodge. So, while they have made a home in Melbourne, ash trees, when out of place, may also play a role in dispossession of other ways of life. Across most of the state, desert ash (Fraxinus angustifolia or Fraxinus oxycarpa) are listed as naturalised and there is a stretchy distinction to be made between native, introduced, naturalised and invasive plants and animals. I suppose I wonder if bringing the trees here was for early colonists a way of bringing their ancestors with them. I have heard anecdotal evidence (through conversations with community activists as part of the Elsternwick Park Association) that during the leaner months some Eastern Rosellas will feed on the ash keys (the seeds are called keys or samaras) when other preferred food sources are scarce. It makes me happy to learn that ash trees are becoming good neighbours to these birds (Kimmerer 2013, 128).

Walking through my new neighbourhood, there are many ash stories: a eucalypt and an ash grow as though entwined in an embrace. Near the canal, a huge ash tree, growing in three trunks, has a 
broken branch that has fallen on the ground and is still growing. There is a street completely lined with a variety of desert ash (Fraxinus angustifolia or Fraxinus oxycarpa), which flowered early this year in the middle of June where in their natural habitats they would flower in late spring. The desert ash was not the focus of The Ash Project because they originate from southern Europe and, while susceptible to the disease that is killing their northern European cousin (Fraxinus excelsior), they are not as vulnerable. They are similar in many ways, except their buds are a different colour; they don't grow as tall and their leaves turn yellow before they fall from the tree. After spending three years with ash trees, I notice them everywhere in Melbourne. But that is not to say that they appear to be flourishing. While there are many, in some ways they don't appear to have acclimatised well. They are not as tall as they might be, they show signs of stress associated with dieback, and their flowering and flushing patterns seem to be affected by the changing climate. In preparing for this article, and because I want to know how they are faring, I called a number of local and municipal arborists, including the ones responsible for ash in my neighbourhood, to ask if ash dieback had been found in Australia. No one could tell me. I also wanted to know why the trees were flowering at strange times of year. There was some speculation that the ash trees had found the dry years hard. At a deeper level I wonder who is watching out for these trees: has ash dieback arrived here? Or are these trees behaving strangely because of the fires, drought, soil and missing fungal associations? How might we extend care to these figures of colonial displacement?

Planting trees is one of many restorative projects that could conserve or transform just some part of our planetary environment in the face of catastrophic climate change. But perhaps this is pointless without a cultural transformation that shifts Western empirical thinking about human beings and our role as nature, within nature, transforming nature. The Ash Project involved walks across many landscapes: in groups we walked with artists, scientists, forest researchers, ethnobotanists, lichenologists, asylum seekers, bird watchers, children, government advisers, tree wardens and many others. Through walking, I learnt everything I could about ash trees: I learnt their stories, science, shape, taxonomies, materials, environments, connections to other species; I learnt how light falls through their leaves; I learnt how to say ash in ancient languages. I learnt how to think with and though a network of relations that make up a human response to crisis. I am not certain that I learnt the ash trees language. I learnt that walking is one way of turning towards this ethical relationality with plants, and one way of being in and among our haunted landscapes.

\section{Ash Walks}

Through The Ash Project it became clear that to feel a sense of loss we must first encounter the recognition, kinship or friendship that precedes loss. Thus, our first challenge as curator and artists was to engage the public in the question: "what is an ash tree?" For many reasons, knowledge of trees has waned through Britain, and many newly arrived migrants, urban populations and children are not given opportunities to learn about the place and its plants. We encountered a population in which only $15 \%$ of people could recognise an ash tree. We started with tree identification walks, leading many people in towns and parks across Kent in walks to distinguish what makes each tree special. Walking became a way of sharing collectively, learning together so 
that we might engage in the deeper knowledge of the damage that has been done. To bring us into closer encounter with trees and their stories. The Ash Project might only have provided a focal point for learning to recognise the ash tree in our landscapes. But on some level that leaves a mark. The events we staged allowed a sense of recognition that might be a precondition for grief to manifest, to be shared, together, in conversation, walking, witnessing, making and unmaking.

Through The Ash Project we asked: what would we call a process that acknowledged the flow of life and death, recovery and loss, and a memorial that could speak of an urgency to recognise kinship with other forms of life in distress? Perhaps we might perform acts of walking, remembering, and experiencing to produce a collective sense of love or care that might also acknowledge our complex shared histories in multi-species entanglements of loss. Zoe Todd, citing Papaschase Cree scholar Dwayne Donald, calls for an 'ethical relationality': “This ethic holds that the past occurs simultaneously in the present and influences how we conceptualize the future. It requires that we see ourselves related to, and implicated in, the lives of those yet to come" (Todd 2015, 250). Donald describes it as an "enactment of ecological imagination" (249). This enactment would resist the temptation of Western agents to define the terms of the ecological crisis and at the same time resist the Cartesian dualisms inherent in the science that underpins this framing. An ethical relation would ask us instead to attend to the network of kin (human and non-human) that give us life, living in a way that is closer to and more implicated in the histories that tie us together in place.

Collective walking enables a slow, sensuous, and embodied relationship to place. It requires a commitment to each other, to building knowledge with a group of people, sharing fragments, stories, folklore, ancient remedies. The collective walks that The Ash Project produced were a way of remembering our connection to the trees around us. Adam Chodzko's artist walk in East Blean Wood imagined a funeral procession for ash taking place in the not-too-distant future. The artist instructed the audience, in moments of walking single file in silence, moments of whispering to each other, moments of seeking out the affect within the wood, "find the angriest part of the wood" and plug into trees for deeper listening. He asked us through various actions to feel our way through a forest filled with emotion, stories, and speculations. Walking, and in particular walking in groups, enables a different kind of speaking with, creating interactions with others and with other-than-human forms of life through an imagination that shapes how the body feels itself in relation to place. Walking is an act that asks us to conceptualise the future, each step, each breath moves from past, present and future in seconds. It might be a way of coalescing or metabolising information with and through the body, allowing us to feel something that data and statistics about climate change and ecological loss fails to do. Collective walking encourages an embodied "ecological imagination" (249). While other kinds of being outside might also have a similar intention, perhaps camping, bush craft workshops, laying under trees, painting, drawing or forest bathing-all of which we experimented with through The Ash Project-walking is an active process that reminds us at a kinaesthetic level of our feeling for and being within the web of life. This is a practice that might mark the beginning of a memorial, a process, a spell against forgetting that encompasses our complicity in the making live and letting die of the Anthropocene. 


\section{Ash and Grieving}

Catriona Sandilands writes in her text, Melancholy Natures, Queer Ecologies (2010), that eco-tourism or pilgrimage merely produces a spectacle, which, instead of deepening our sense of loss, delays or suspends such a process. She writes, "In short, there is lots of evidence of environmental loss, but few places in which to experience it as loss, to even begin to consider that the diminishment of life that surrounds us on a daily basis is something to be really sad about, and on a personal level" (Mortimer-Sandilands 2010, 338). Perhaps creative practices might act as a refuge for experimenting with producing the conditions to make such places available. As the curator responsible in this case, it would be presumptuous to suggest that we all shared this grief, perhaps only a few of us mourned, or felt loss, while others looked on with interest. Does grief produce kinship? Or does kinship make grief available to us? I would say yes, but I can't attest to the experience of the thousands of people we asked to join us.

Haraway and Tsing echo each other in thinking about our capacity for being attuned to haunted landscapes as essential to our ability to grieve with other forms of life and to the specificities of loss on a damaged planet. For Haraway, grieving is a strategy for staying with the trouble: "Grief is the path to understanding entangled shared living and dying; human beings must grieve with, because we are in and of this fabric of undoing" $(2016,39)$. Haraway speculates that if we can't learn to live with ghosts, then perhaps we can't learn to think with the present moment. Mourning and the work of mourning requires something of us, it is often outwardly expressed as ritual, as action in and through time. It is a process that will be transformative without knowing the outcome. As Judith Butler writes, "There is losing as we know, but there is also the transformative effect of loss, this latter cannot be charted or planned" $(2004,14)$. Butler's work on mourning, in her book Precarious Life, asks questions about what might make a life (human in her theorising) grievable. The same question is being asked and needs to be asked here and elsewhere of our relations to the plant life we all depend upon.

Early in 2020 as the world watched Australian forests on fire, the sense of loss was palpable across the planet. Butler proposes that mourning with others produces a collective sense, a "we," through revealing our very interdependence on each other. In the case of plants, it reveals our interdependence on the web of relations that make all life liveable. Ash trees have a global history, attending to this making and unmaking reveals again that we are living within a system that is implicated in the living and dying of many species across the planet. The experience of grief in the case of ash is underscored by the knowledge of our own complicity. "To grieve, and to make grief itself into a resource for politics, is not to be resigned to inaction, but may be understood as the slow process by which we develop a point of identification with suffering itself" (Butler 2004, 32). When I entered the wood on my last night working in the Kent Downs in 2019, I didn't expect to find the fallen trees, their giant stumps still wet with sap. But I felt something move within me. I stopped the car in the middle of the road, got out and cried into the mist. Grief, when it is extended towards plant life under threat, might be a prefigurative practice for changing our relationships to place, to more than human liveliness, to ourselves. 
Throughout The Ash Project, I was often asked 'What can we do to save the ash?' In response, our artistic and curatorial team posed, perhaps if we can't save the ash trees, we can learn to be together among the living and dying, attending to our part of the Earth with curiosity, care and a different sense of attention. Perhaps if there were to be an act of memorial or active remembering that we could all perform, across our locations, it might be a process of developing intimate knowledge of a species at risk. Saying their names in many languages, retelling their stories, following their histories or casting a spell as I have attempted with the ash tree. All so that we might learn the patchy practices of living with, and grieving for, other forms of life.

\section{Acknowledgements}

I am writing this on the lands of the people of the Boon wurrung and Woi wurrung language groups of the Kulin Nations, I pay respects to Indigenous knowledge of trees, plants and waterways that has sustained care for Country on these lands for over 60,000 years. An early abridged version of this essay appeared in Tree Story: a reader that was published by Monash University Museum of Art and Monash University Publishing in 2021. Edited by Charlotte Day and Mel Ratliff to coincide with the exhibition Tree Story, curated by Charlotte Day with Dr Brian Martin.

I would like to thank Kara Ward and Charles Caroll at the Royal Botanic Gardens of Melbourne for their openness and insights; Christian Renaud from the City of Port Phillip; and Rob Mineo from the Council Arboriculture Victoria for sharing knowledge of local ash care with me. Thanks also to Charlotte Day, Quentin Sprague, and Mel Ratliff for the invaluable feedback on the early version of this writing. Thank you also to MADA Curatorial Practice colleagues and mentors for reading drafts of this essay as part of our studies, especially Helen Hughes and Spiros Panigirakis. I also want to acknowledge the huge network of researchers, scientists, writers, artists, and experts that I gleaned knowledge from over the three years of The Ash Project. Thank you to the artists Heather Ackroyd and Dan Harvey and the co-curator of The Ash Archive and Ash Walks Rose Thompson for working alongside me in shaping The Ash Project. With huge thanks to Nick Johannsen Director of the Kent Downs for sharing and imparting his love of ash to me and to the rest of the Kent Downs team for having me in the barn.

The Ash Project is an initiative of the Kent Downs. The project was funded by the Heritage Lottery Fund, Arts Council England, Kent County Council, Woodland Trust and North Downs Way. It involved a partnership with Imperial College London, Creative Folkestone, Folkestone Triennial, Forestry Commission, The Tree Council, Woodland Trust, Kent County Council, Kent Tree Wardens University of Kent, Turner Contemporary and Whitstable Biennale. www.theashproject.co.uk 


\section{Works Cited}

Abram, Christopher. 2019. Evergreen Ash: Ecology and Catastrophe in Old Norse Myth and Literature. Charlottesville: University of Virginia Press. https://doi.org/10.2307/j.ctvbcd06q

Andersson, Pierre, S. Johansson, Jan Stenlid, and Anders Broberg. 2009. "Isolation, identification and necrotic activity of viridiol from Chalara fraxinea, the fungus responsible for dieback of ash." Forest Pathology 40: 43-46. https://doi.org/10.1111/j.1439-0329.2009.00605.x

Bennett, George. 1862. Acclimatisation and Its Eminent Adaption to Australia: A Lecture. Melbourne: WM Goodhugh \& Co. https://doi.org/10.5962/bhl.title.146539

Broome, Alice, and Ruth J. Mitchell. 2017. "Ecological impacts of ash dieback and mitigation methods." Forestry Commission Research Note 029. https://www.forestresearch.gov.uk/research/ecological-impacts-of-ashdieback-and-mitigation-methods/

Butler, Judith. 2004. Precarious Life: The Powers of Mourning and Violence. London and New York: Verso.

Clarke, John P. 2019. Between Earth and Empire: From the Necrocene to the Beloved Community, San Francisco: PM Press.

Davis, Heather, and Zoe Todd. 2017. "On the Importance of a Date, or Decolonizing the Anthropocene." ACME: An International Journal for Critical Geographies 16 (4): 761-80.

Department for Environment, Food \& Rural Affairs. 2019. "Policy paper: Ash tree research strategy 2019, Conserving our ash trees and mitigating the impacts of pests and diseases of ash: A vision and high-level strategy for ash research." Accessed 12 June 2021. https://www.gov.uk/government/publications/ashtree-research-strategy-2019

Forest Research. 2021. Ash dieback (Hymenoscyphus fraxineus). Accessed 12 June 2021.

https://www.forestresearch.gov.uk/tools-and-resources/fthr/pest-and-disease-resources/ash-diebackhymenoscyphus-fraxineus/

Goberville, Eric, Nina-Coralie Hautekèete, Richard R. Kirby, Yves Piquot, Christophe Luczak, and Grégory Beaugrand. 2016. "Climate change and the ash dieback crisis." Scientific Reports 6: 1-7. https://doi.org/10.1038/srep35303

Haraway, Donna J. 2016. Staying with the Trouble: Making Kin in the Chthulucene. Durham, NC: Duke University Press. https://doi.org/10.2307/j.ctv11cw25q

Haraway, Donna, and Anna Tsing. 2019. "Reflections on the Plantationocene: A Conversation with Donna Haraway and Anna Tsing." Edge Effects, 18 June. https://edgeeffects.net/haraway-tsing-plantationocene/

Hesiod. 2017. The Poems of Hesiod: Theogony, Works and Days, and the Shield of Herakles. Berkeley: University of California Press.

Khela, S., and S. Oldfield. 2018. "Fraxinus Excelsior." IUCN Red List of Threatened Species 2018. Accessed 1 October 2020. https://doi.org/10.2305/IUCN.UK.2018-1.RLTS.T203367A67807718.en

Kimmerer, Robin Wall. 2013. Braiding Sweetgrass. Minneapolis: Milkweed Editions.

Lever, Christopher. 2011. "Acclimatisation Societies." In Encyclopedia of Biological Invasions, edited by Daniel Simberloff and Marcel Rejmanek, 38-43. Berkeley: University of California Press.

Macdonald, Helen. 2015. "Dead Forests and Living Memories." New York Times. Accessed 13 June 2021. https://www.nytimes.com/2015/09/20/magazine/dead-forests-and-living-memories.html

MacKillop, James. 2004. A Dictionary of Celtic Mythology. Oxford: Oxford University Press.

Mendes, Margarida. 2017. "Molecular Colonialism." In Matter Fictions, edited by Margarida Mendes, 125-140. Berlin: Sternberg.

Moore, Jason W. 2015. Capitalism in the Web of Life: Ecology and the Accumulation of Capital. London: Verso. 
Mortimer-Sandilands, Catriona. 2010. "Melancholy Natures, Queer Ecologies." In Queer Ecologies: Sex, Nature, Politics, edited by Catriona Mortimer-Sandilands and Bruce Erickson, 331-358. Indiana: Indiana University Press

NASA. 2021. "Global Climate Change: Vital Signs of the Planet." Accessed 13 June 2021. https://climate.nasa.gov/

Natural England. 2021. "Site Improvement Plan: Folkestone to Etchinghill Escarpment (SIP088)." Accessed 13 June 2021. http://publications.naturalengland.org.uk/publication/5748653180321792

Potter, Clive, and Julie Urquhart. 2017. "Tree disease and pest epidemics in the Anthropocene: A review of the drivers, impacts and policy responses in the UK." Forest Policy and Economics: 61-68.

https://doi.org/10.1016/j.forpol.2016.06.024

State of Victoria. 2020. "Invasiveness Assessment - Desert ash (Fraxinus angustifolia) in Victoria." Victorian Resources Online, Agriculture Victoria. Accessed 1 October 2020.

http://vro.agriculture.vic.gov.au/dpi/vro/vrosite.nsf/pages/invasive_desert_ash

Stafford, Fiona. 2016. The Long, Long Life of Trees. New Haven: Yale University Press.

Todd, Zoe. 2015. "Indigenising the Anthropocene." In Art in the Anthropocene: Encounters Among Aesthetics, Politics, Environments and Epistemologies, edited by Heather Davis and Etienne Turpin, 241-54. London: Open Humanities Press.

Tout-Smith, Deborah. 2003. "Acclimatisation Society of Victoria." Museums Victoria Collections. Accessed 13 June 2021. https://collections.museumsvictoria.com.au/articles/1803

Tsing, Anna Lowenhaupt. 2015. The Mushroom at the End of the World: On the Possibility of Life in Capitalist Ruins. Princeton: Princeton University Press. https://doi.org/10.1515/9781400873548

Von Mueller, Baron Ferdinand. 1876. "Application of Phytology in relation to Industrial Pursuits: A Popular Discourse." In Forest Culture and Eucalyptus Trees, edited by Ellwood Cooper, 84-129. San Francisco: Cubery and Company.

Webber, Bruce L, Rieks D van Klinken, and John K. Scott. 2014. "Invasive Plants in a Rapidly Changing Climate: An Australian Perspective." in Invasive Species and Global Climate Change, edited by L.H. Ziska and J.S. Dukes, 169-197. Wallingford, UK: CAB International. https://doi.org/10.1079/9781780641645.0169

Williams, Raymond. 1976. Keywords: A Vocabulary of Culture and Society. Oxford: Oxford University Press.

Woodland Trust. 2021. "Ash." Accessed 13 June 2021. https://www.woodlandtrust.org.uk/trees-woods-andwildlife/british-trees/a-z-of-british-trees/ash/

\section{Biography}

Madeleine Collie is a writer, artist and curator who now lives and works on the unceded lands of the Boon Wurrung and Wurundjeri people of the Kulin Nations. She led the collective memorial project The Ash Project (2016-2019). She established the Food Art Research Network in 2020 with the support of Custom Food Lab. She has an extensive history in creating and producing projects working across disciplines and always with others to blur the boundaries between experience and knowledge creation. She has presented work in Australia, UK, Spain, Germany, Finland and Singapore. She is a PhD candidate in Curatorial Practice at Monash University and holds a Masters by Research in Curatorial/Knowledge at Goldsmiths College. She is a Teaching Associate in the History of Art, Design and Architecture and Curating Practices in the department of Art, Design and Architecture at Monash University, Melbourne and a Research Associate for the Centre for Art and Social Transformation.

(C) 2021 Madeleine Collie

Except where otherwise noted, this work is licensed under a Creative Commons Attribution-

NonCommercial-ShareAlike 4.0 International License. 